\title{
Amendment of an Acid Mine Soil with Compost and Polyacrylate Polymers Enhances Enzymatic Activities but may Change the Distribution of Plant Species
}

\author{
Amarilis de Varennes • Cristina Cunha-Queda • \\ Guiwei Qu
}

Received: 5 January 2009 / Accepted: 14 July 2009

(C) Springer Science + Business Media B.V. 2009

\begin{abstract}
Many soils derived from pyrite mines spoils are acidic, poor in organic matter and plant nutrients, contaminated with trace elements, and support only sparse vegetation. The establishment of a plant cover is essential to decrease erosion and the contamination of water bodies with acid drainage containing large concentrations of trace elements. We tested the application of compost and polyacrylate polymers to promote the growth of indigenous plant species present in the mine area. Soil treatments consisted of unamended soil (control), soil with mineral fertilizers only, soil with fertilizer plus compost, soil with fertilizer plus polyacrylate polymers, and soil with fertilizer plus both amendments. Half of the soil was grown with Briza maxima L. (greater quaking grass), Chaetopogon fasciculatus (Link) Hayek (chaetopogon), and Spergularia purpurea (Persoon) G. Don fil. (purple sandspurry), while the remainder was left bare. In the absence of plants, the greatest improvements in soil conditions were obtained by the application of both amendments, which was associated with the greatest values of protease, acid phosphatase, and $\beta$-glucosidase, whereas the activity of cellulase and microbial respiration were similar in soil amended with compost or
\end{abstract}

A. de Varennes $(\bowtie) \cdot$ C. Cunha-Queda $\cdot$ G. Qu

Instituto Superior de Agronomia,

Technical University of Lisbon (TULisbon),

Tapada da Ajuda,

1349-017 Lisbon, Portugal

e-mail: adevarennes@isa.utl.pt polymer. Dehydrogenase activity was greatest in soil with compost (with or without polymer), whereas urease activity was impaired by both amendments. In the presence of plants, the application of both amendments led to the greatest activities of protease, urease, $\beta$-glucosidase, cellulase, and microbial respiration, but acid phosphatase was mainly enhanced by polymer and dehydrogenase was increased by compost. Plant growth was stimulated in all treatments compared with unamended soil, but the greatest value for total accumulated biomass was obtained in fertilized soil receiving both amendments. However, species responded differently to treatment: while the growth of $B$. maxima was greatest in soil with compost and polymer, the growth of $C$. fasciculatus responded better to soil with compost, and $S$. purpurea grew better in polymer-amended soil. The amendments tested improved the quality of a mine soil and stimulated plant growth. However, botanical composition likely changes over time with amendments, and this needs to be considered when a large scale application of amendments is projected.

Keywords Enzymatic activities · Compost . Mine soil $\cdot$ Polyacrylate polymers

\section{Introduction}

Many soils derived from pyrite mines spoils are acidic, poor in organic matter and plant nutrients, and 
contaminated with trace elements. The establishment of a plant cover is essential to protect the soil surface and increase evapotranspiration, thereby decreasing wind and water erosion and contamination of water bodies with acid drainage. One approach is to add soil amendments that precipitate or increase metal sorption thereby decreasing the proportion of the total element in soil solution. Some possible amendments include materials used in agriculture such as lime (Geebelen et al. 2003), organic residues (Farfel et al. 2005), and industrial products such as zeolites (Friesl et al. 2003) and insoluble polyacrylate polymers (Guiwei et al. 2008).

Large molecular weight insoluble polyacrylate polymers are composed of long chains with regularly distributed carboxylic groups, neutralized by $\mathrm{Na}^{+}, \mathrm{K}^{+}$, or $\mathrm{NH}_{4}{ }^{+}$. They swell to form gels that contain many times their weight in water and are used in diapers, paper towels, and feminine products. It is estimated that over $130 \mathrm{Gg}$ of polyacrylates are used annually in such products (Martin 1996). Hydrophilic polymers are also marketed as "superabsorbent polymers," under different trade names, for incorporation into soils and substrates when an increase in the waterholding capacity is desirable.

Hydrophilic insoluble polymers enhance plant growth by increasing the water-holding capacity of the soil (Al-Humaid and Moftah 2007; Boatright et al. 1997; de Varennes et al. 1999), supplying the cation present (de Varennes et al. 1999; Silberbush et al. 1993), and decreasing the bioavailability of some trace elements (de Varennes and Queda 2005; de Varennes et al. 2006; Lindim et al. 2001). Recently, Guiwei et al. (2008) reported that mixed cation polyacrylate polymers promote the growth of orchard grass in a mine soil.

The amount of municipal solid wastes generated every year in the EU-15 is about 200 million tonnes (DG Env.A.2. 2003) and environmentally sound strategies for their recycling must be developed. The use of composts produced from mixed municipal solid wastes in agriculture can have adverse effects as the trace elements present impair the agro-ecosystem and can be taken up by edible plants (Gaskin et al. 2003; Korboulewsky et al. 2002). An appropriate alternative is to use them in land rehabilitation (Pichtel et al. 1994). They promote the establishment of a vegetation cover by providing essential nutrients for plant growth, raising the $\mathrm{pH}$, and chelating toxic metals (Alvarenga et al. 2008a; Brown et al. 2003; Clemente et al. 2006; Walker et al. 2003; Wong 2003).

Several studies have evaluated the effect of organic amendments (such as compost from municipal solid waste or biosolids) on heavy metal-contaminated mine soils. Most of them focused on the effect of amendments on bioavailability of trace elements (Alvarenga et al. 2008a; Brown et al. 2003; Gaskin et al. 2003; Illera et al. 2000; Pérez-de-Mora et al. 2006b, 2007; Walker et al. 2003, 2004) while only a few reported changes on microbial activity and soil enzymes (Alvarenga et al. 2008b; Garcia-Gil et al. 2000; Pérez-de-Mora et al. 2005, 2006a).

Soil enzymes catalyze biochemical reactions that are often related to nutrient cycling in the soil. They can be used as indicators of soil quality because of their relationship to soil biological processes and rapid response to changes. No information seems to be available on whether promoting the growth of indigenous plants impacts microbial growth and enzymatic activities of mine soils.

The soil used came from the S. Domingos mine which is located in the Iberian Pyrite Belt. It was explored during the nineteenth and twentieth centuries for $\mathrm{Cu}$ until exploration was discontinued in 1966. The processing of the ore produced large amounts of waste rock and tailings which were deposited on the surface. A wide area of land became contaminated with trace elements and only supports sparse vegetation.

We chose three different species already present in the mine. Briza maxima L. (greater quaking grass) and Chaetopogon fasciculatus (Link) Hayek (chaetopogon) are annual grasses in the family Poaceae. Spergularia purpurea (Persoon) G. Don fil. (purple sandspurry) is an annual or biannual dicot in the family Caryophyllaceae. They are found in poor soils in the Mediterranean area. The first is sometimes grown as an ornamental plant, and the last is used as a medicinal plant in Morocco (Eddouksa et al. 2003; Jouad et al. 2001).

The objectives of the present work were: (1) to identify whether compost from mixed municipal solid waste and polyacrylate polymers either in combination or separately could be used to enhance plant growth in a mine soil and (2) to determine the effect of amendments and plants on soil health. We hypothesized that amendments and a plant cover would increase microbial biomass and soil enzymes, compared with their values in unamended bare soil. 


\section{Material and Methods}

Soil used in the experiment was taken from the S. Domingos mine. The soil was acidic, poor in organic matter and plant nutrients, and with large total contents of $\mathrm{Pb}$ and As (Table 1).

The compost used was derived from unsorted municipal wastes. It had a $\mathrm{pH}$ of 8.0 and was rich in plant nutrients but had large contents of $\mathrm{Na}, \mathrm{Mn}, \mathrm{Cu}$, $\mathrm{Zn}$, and $\mathrm{Pb}$ (Table 1). According to the Working Document on Biological Treatment of Biowaste-2nd Draft (DG Env.A.2. 2001) of the Directorate-General Environment of the European Commission, application of compost from mixed municipal solid should be restricted to land that is not destined for food and fodder production. The compost used falls into this class, considered as "stabilized biowaste" and has metal concentrations below the maximum limits allowed by the DG Env.A.2. (2001) for this quality class (600 mg Cu, $500 \mathrm{mg} \mathrm{Pb}$, and 1,500 mg Zn kg-1 dry weight). It is important to note that $\mathrm{Pb}$ and $\mathrm{As}$ levels in compost were considerably lower than those in the mine soil.

The soil was air-dried and passed through a 2-mm sieve and was divided into five parts: one was used without any addition of fertilizers or amendments, while two received a basal dressing of $200 \mathrm{mg} \mathrm{N}$, $125 \mathrm{mg} \mathrm{P}, 420 \mathrm{mg} \mathrm{K}$, and $25 \mathrm{mg} \mathrm{Mg} \mathrm{kg}{ }^{-1}$ of soil, supplied as ammonium nitrate, calcium dihydrogen phosphate, potassium sulfate, and magnesium sulfate,

Table 1 Characteristics of the soil and compost used in the experiment

\begin{tabular}{lll}
\hline & Soil & Compost \\
\hline Texture & Sandy loam & - \\
pH water & 4.1 & 8.0 \\
Organic C $\left(\mathrm{g} \mathrm{kg}^{-1}\right)$ & 1.1 & 329 \\
Total P $\left(\mathrm{g} \mathrm{kg}^{-1}\right)$ & 0.44 & 7.9 \\
Total K $\left(\mathrm{g} \mathrm{kg}^{-1}\right)$ & 3.1 & 16 \\
Total $\mathrm{Ca}\left(\mathrm{g} \mathrm{kg}^{-1}\right)$ & 0.2 & 95 \\
Total $\mathrm{Mg}\left(\mathrm{g} \mathrm{kg}^{-1}\right)$ & 0.3 & 13 \\
Total $\mathrm{Na}\left(\mathrm{g} \mathrm{kg}^{-1}\right)$ & 0.3 & 12 \\
Total $\mathrm{Mn}\left(\mathrm{mg} \mathrm{kg}^{-1}\right)$ & 17 & 240 \\
Total Cu $\left(\mathrm{mg} \mathrm{kg}^{-1}\right)$ & 91 & 273 \\
Total $\mathrm{Zn}\left(\mathrm{mg} \mathrm{kg}^{-1}\right)$ & 47 & 560 \\
Total $\mathrm{Pb}\left(\mathrm{mg} \mathrm{kg}^{-1}\right)$ & 6160 & 307 \\
Total As $\left(\mathrm{mg} \mathrm{kg}^{-1}\right)$ & 2730 & 15 \\
\hline
\end{tabular}

respectively. One of the latter received compost $15 \mathrm{~g}$ $\mathrm{kg}^{-1}$ of soil (dry weight basis). The remaining two parts received $\mathrm{P}$ and $\mathrm{Mg}$ at the same rate as before and $0.4 \%$ of polyacrylate polymers (half with $\mathrm{K}^{+}$as counter ion and half $\mathrm{NH}_{4}^{+}$). These provided the same amount of potassium and nitrogen as the mineral fertilization. Compost at the same rate as before was applied to half of the soil with polymer. In the end, five treatments were obtained: no fertilizer or amendment, mineral fertilizer only, fertilizer plus compost, fertilizer plus polyacrylate polymers, and fertilizer plus both amendments. For each treatment, eight pots (upper diameter $=21 \mathrm{~cm}$; height $=18 \mathrm{~cm}$ ) were filled with $4 \mathrm{~kg}$ of soil.

All pots were saturated with deionized water, covered, and left to drain for $24 \mathrm{~h}$. They were then weighed every day, and water was applied to maintain $75 \%$ of the water-holding capacity of each soil treatment. Pots were kept in an outdoor area protected with a net and taken to an adjacent glasshouse when it rained.

After 1 month of incubation, half of the pots (four per treatment) were left without plants and used as control (bare soil). The remaining pots were sown with B. maxima L., S. purpurea (Persoon) G. Don fil., and $C$. fasciculatus (Link) Hayek. Three cuts were carried out at 40, 90, and 125 days after sowing. After the second cut, $50 \mathrm{mg} \mathrm{N} \mathrm{kg}^{-1}$ of soil was added as ammonium nitrate.

Collected shoots were separated by species, washed with deionized water, dried at $65^{\circ} \mathrm{C}$, and weighed. At the end of the experiment, the soil was collected and passed through a 2-mm sieve prior to analysis.

Fresh soil subsamples from all pots were analyzed for dehydrogenase activity according to Tabatabai (1994). Basal respiration was determined using the MicroResp apparatus (Campbell et al. 2003).

Other soil subsamples were frozen until analyzed for several enzymatic activities.

Criteria for choosing enzymes were based on previous experience of their sensitivity to management of mine soils (Guiwei et al. 2008). Dehydrogenase is an intracellular enzyme used as an index of overall microbial activity (Nannipieri et al. 2002). Cellulases are enzyme systems that degrade cellulose, an important plant-derived input into soils. $\beta$ glucosidase plays a critical role in the release of sugars that act as energy source for soil micro- 
organisms. Protease and urease are involved in the release of inorganic $\mathrm{N}$ and acid phosphatase in $\mathrm{P}$ cycling in acid soils.

Cellulases were determined according to Hope and Burns (1987). In the context of this work, the term refers to the combined action of endo-1,4- $\beta$-Dglucanase (EC 3.2.1.4), exo-1,4- $\beta$-D-glucanase (EC 3.2.1.91), and $\beta$-D-glucosidase (EC 3.2.1.21) on Avicel, a purified depolymerized alpha cellulose.

Acid phosphomonoesterase (EC 3.1.3.2) and $\beta$ glucosidase (EC 3.2.1.21) were measured by incubating the soil with a substrate containing a $p$-nitrophenyl moiety (Eivazi and Tabatabai 1977, 1988). Acid phosphomonoesterase (acid phosphatase) catalyzes hydrolyses of organic $\mathrm{P}$ esters and anhydrides of phosphoric acid into inorganic P. $\beta$-glucosidase catalyzes the hydrolysis of carbohydrates with $\beta$-Dglucoside bonds.

Urease (EC 3.5.1.5), which catalyzes the hydrolysis of urea to $\mathrm{CO}_{2}$ and $\mathrm{NH}_{3}$, was determined according to the method described by Kandeler and Gerber (1988).

\subsection{Statistics}

All data were analyzed for variance by the general linear model, and mean separation was performed using the Newman-Keuls test at $p \leq 0.05$. Principal component analysis (PCA) and cluster analysis were performed to detect key parameters contributing to data variability and relationships among plant species, soil microbial respiration and activity, and soil enzymes. These analyses were also used to identify the best treatment to improve soil quality.

\section{Results}

\subsection{Plant Growth}

Plants grew very poorly in unamended unfertilized soil, and B. maxima did not even survive (Table 2). Application of mineral fertilizer alone resulted in increased growth of all three species, with a total biomass of $20.8 \mathrm{~g} / \mathrm{pot}-23$ times greater than that of control. Application of compost or polymer together with mineral fertilization enhanced biomass accumulation further by about $69 \%$, but total biomass accumulation was greatest in fertilized soil containing both amendments - $46.6 \mathrm{~g} / \mathrm{pot}$. The three species responded differently to treatments. Plant biomass accumulated over three cuts was greatest for $B$. maxima in soil with polymer and compost, while $C$. fasciculatus responded better to soil with only compost, and $S$. purpurea preferred polymeramended soil (Table 2).

\subsection{Microbial Respiration and Activity}

The dehydrogenase activity in unamended bare soil was small and not affected by a plant cover (Fig. 1). Mineral fertilizer application slightly increased dehydrogenase activity, while the presence of polymer or compost increased it further. The greatest value was obtained in compost-amended soil with plants present (Fig. 1). Plants enhanced soil dehydrogenase activity in treatments with mineral fertilizer except when both compost and polymer were also present.

Microbial respiration (basal respiration) was always enhanced by the presence of plants. It also increased in all treatments compared with unfertilized unamended soil. Its greatest value was obtained in soil containing both polymers and compost, but there were no significant differences among the other three treatments that received fertilizer (Fig. 1).

\subsection{Soil Enzymes Associated with Nutrient Cycling}

In bare soil, phosphatase and $\beta$-glucosidase did not respond to mineral fertilizer application, whereas it increased urease, protease, and cellulase activities (Fig. 2). The greatest activities of protease, phosphatase, and $\beta$-glucosidase in bare soil were obtained in soil receiving both amendments. Cellulase responded similarly to both amendments, while the greatest value for urease was obtained in fertilized bare soil, followed by bare polymer-amended soil (Fig. 2).

The presence of plants stimulated the activities of all enzymes except urease relative to values in bare soil (Fig. 2). With plants present, the application of both amendments resulted in protease, $\beta$-glucosidase, and cellulase having the greatest activity in soil. Phosphatase achieved its greatest activity in polymeramended soil and in the presence of plants, whether or not compost was also applied. In contrast, urease activity was greater in bare soil compared with that with plants for all treatments except control, where plants grew very poorly. In the latter case, there were 
Table 2 Biomass accumulation ( $g / p o t ~ \pm 1$ SD) by three species grown for 125 days (three cuts) in a mine soil with five different treatments

\begin{tabular}{llllc}
\hline Treatment & B. maxima & C. fasciculatus & S. purpurea & Total biomass \\
\hline None & NF & $0.2 \pm 0.1 \mathrm{c}$ & $0.7 \pm 0.4 \mathrm{c}$ & $0.9 \pm 0.4 \mathrm{~d}$ \\
MF & $3.4 \pm 1.1 \mathrm{~d}$ & $11.6 \pm 1.2 \mathrm{~b}$ & $5.8 \pm 3.3 \mathrm{~b}$ & $20.8 \pm 1.9 \mathrm{c}$ \\
MF + Polymers & $11.0 \pm 1.1 \mathrm{~b}$ & $14.0 \pm 0.5 \mathrm{~b}$ & $10.0 \pm 1.5 \mathrm{a}$ & $34.9 \pm 0.7 \mathrm{~b}$ \\
MF + Compost & $8.2 \pm 1.5 \mathrm{c}$ & $23.7 \pm 3.5 \mathrm{a}$ & $3.4 \pm 1.7 \mathrm{~b}$ & $35.3 \pm 4.6 \mathrm{~b}$ \\
MF + Polymers + Compost & $27.2 \pm 1.5 \mathrm{a}$ & $14.6 \pm 2.8 \mathrm{~b}$ & $4.9 \pm 1.7 \mathrm{~b}$ & $46.6 \pm 2.1 \mathrm{a}$ \\
\hline
\end{tabular}

Values in a column followed by the same letter are not significantly different as estimated by the Newman-Keuls test at $p<0.05$ $M F$ mineral fertilizer, $N F$ not found

no significant differences between either treatment (with or without plants).

\subsection{Relationships among Parameters}

As the relationships between parameters obtained in bare soil or in unamended soil with plants were not different, the data were analyzed together. The four replicates of each treatment were close to each other, with linkage distances smaller than 0.6. Overall, the best treatment in bare soil was obtained by the application of both amendments as this treatment was on the upper right quadrant of the PCA map, corresponding to the greatest loadings for all soil parameters tested with the exception of urease (Table 3).

The relationship between soil parameters in fertilized or amended soil changed when plants were present. The four replicates of each treatment were again grouped together, with linkage distances smaller than 0.7. Soil parameters had all positive loadings on either PC 1 or PC 2 (Table 4), and the best treatment to improve soil quality should be, therefore, located on the upper right quadrant of the PCA map. The treatment with both amendments was located farthest to the right (positive side of PC 1), but the treatment with compost on its own was further up on the positive side of PC 2 (Fig. 3) due to the large loading of dehydrogenase activity (Table 4). This seems to be related to the fact that the loadings of parameters corresponding to biomass accumulation were different for each species (Table 4) and reflected the results already presented: $B$. maxima was favored by both amendments (a positive loading on PC 1), C. fasciculatus by compost (a positive loading on PC 2) and S. purpurea by polymer application (a negative loading on PC 2).

\section{Discussion}

The total contents of $\mathrm{Pb}$ and $\mathrm{As}$ in the mine soil were much greater than the maximum allowable in soils to be used in the production of crops or fodder (Dudka

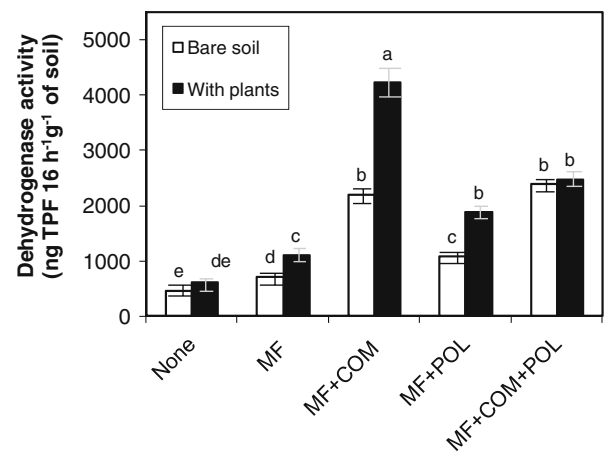

Fig. 1 Effects of treatments and plants on dehydrogenase activity (left) and microbial respiration (right). In each figure, values in a column followed by the same small letter are not

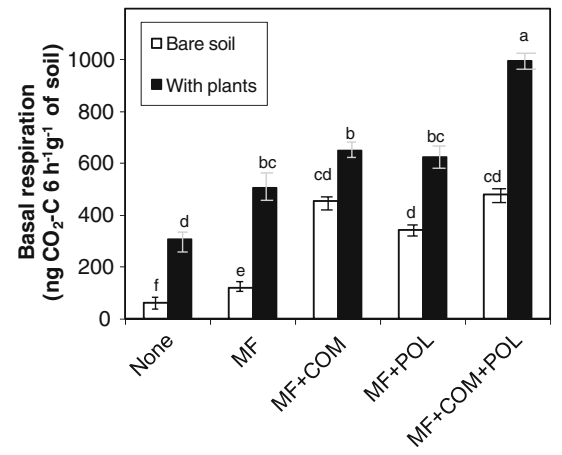

significantly different as estimated by the Newman-Keuls test at $p<0.05$. TPF triphenylformazan; $M F$ mineral fertilizer; $C O M$ compost; $P O L$ polymers 
Fig. 2 Effects of treatments and plants on soil enzymatic activities. For each enzymatic activity, columns with the same letter are not significantly different as estimated by the NewmanKeuls test at $p<0.05 . M F$ mineral fertilizer; $C O M$ compost; $P O L$ polymers
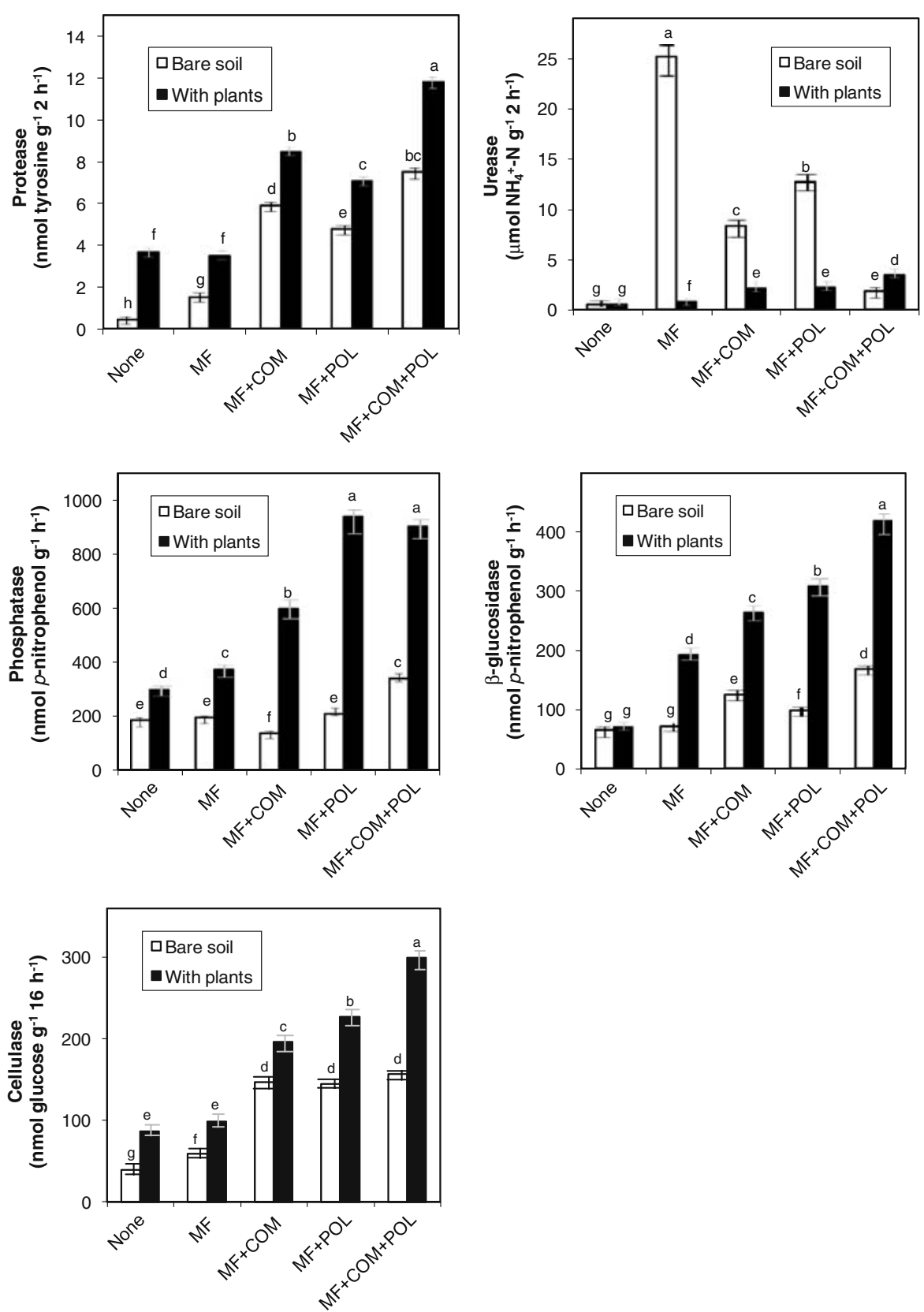

and Miller 1999). Therefore, the most effective approach to improve soil quality and decrease erosion seemed to be the promotion of the growth of plants already present in the area. This was the approach taken in this experiment.

The small pool of plant nutrients in the mine soil was a major limiting factor for plant growth. In consequence, plant growth was greatly stimulated even by the application of mineral fertilizer. The joint effect of plants with their root exudates and mineral nutrients led to enhanced values of all soil parameters tested-microbial respiration and activity (as evaluated by dehydrogenase) and soil enzymes related with nutrient cycling. Application of fertilizers (N, P, and K) do not necessarily have a clear effect on their own, as they can sometimes enhance and other times inhibit soil enzymes (Iyyemperumal and Shi 2008; Yang et al. 2008). In the present experiment, fertilizer application 
Table 3 Loadings for each variable along PC1 and PC2 resulting from principal component analysis of parameters in bare soil or in unfertilized soil with plants

\begin{tabular}{lll}
\hline Variable & PC 1 & PC 2 \\
\hline Urease activity & -0.0180 & $-0.8426^{\mathrm{a}}$ \\
Phosphatase activity & 0.1783 & $0.7675^{\mathrm{a}}$ \\
Glucosidase activity & $0.8657^{\mathrm{a}}$ & 0.1845 \\
Dehydrogenase activity & 0.4390 & $0.7497^{\mathrm{a}}$ \\
Cellulase activity & $0.9564^{\mathrm{a}}$ & 0.0716 \\
Protease activity & $0.9352^{\mathrm{a}}$ & 0.2750 \\
Microbial respiration & $0.8795^{\mathrm{a}}$ & 0.2143 \\
\hline
\end{tabular}

PC1 first principal component; $P C 2$ second principal component

${ }^{\mathrm{a}}$ Marked correlations are significant (correlation coefficient $>0.7$ )

to bare soil resulted in increased activities of urease, cellulase, and protease and enhancement of microbial respiration and activity. However, with the exception of urease, the increase was modest compared with that obtained in amended soil. Urease had the greatest activity in fertilized unamended bare soil.

The presence of plants is frequently associated with increased enzymatic activity. For example, the presence of Agrostis stolonifera L. restored microbial properties of a soil contaminated by a mine accident (Pérez-de-Mora et al. 2005). In the present experiment, plants stimulated microbial respiration and the activities of protease, acid phosphatase, and cellulase even in soil without any fertilizer or amendments.

Application of compost from mixed solid waste increased soil $\mathrm{pH}$ (from 4.5 to about 6.5), and provided plant nutrients (data not shown). It would be expected to introduce organic $\mathrm{C}$ and microorganisms into the soil, resulting in a large difference in dehydrogenase activity between bare soil and soil amended with compost. Importantly, polymer application also increased dehydrogenase activity and basal respiration in bare soil compared with soil receiving only mineral fertilizer. Although they contain organic $\mathrm{C}$, polyacrylate polymers are only slowly degraded in soils (Martin 1996) and will not contribute to carbon nutrition of soil organisms to any great extent. Except in unfertilized controls, mineral fertilizer application in treatments without polymers compensated for the presence of counter ions $\mathrm{NH}_{4}{ }^{+}$ and $\mathrm{K}^{+}$. Therefore, the direct effects of polymer application could only be due to the capacity to retain water and chelate trace elements (de Varennes et al.
1999; de Varennes et al. 2006). It appears that these effects led to the formation of microsites rich in water and with smaller concentrations of trace elements that favor plants and soil organisms (Guiwei et al. 2008).

Enhanced activity of soil enzymes following compost application is consistent with the results of Pérez-de-Mora et al. (2005, 2006a). There is no previous information on the effects of polymer application to bare mine soil.

Principal component analysis showed large positive loadings of all bare soil parameters except urease on either PC 1 or PC 2, suggesting that the greatest improvement in soil quality was obtained in fertilized soil receiving both amendments, as this treatment was located on the upper right quadrant of the PCA map (Fig. 4). Urease had a large negative loading on PC 2, consistent with the report of Dick et al. (1988) who suggested that urease activity decreases with the addition of the end product of the enzymatic reaction $\left(\mathrm{NH}_{4}{ }^{+}\right)$. The activity of this enzyme activity was impaired by polyacrylate polymers containing ammonium as counter ion (Guiwei et al. 2008), while mineralization of compost will also result in the release of ammonium ion. Urease is also inhibited by soil salinity (Cookson 1999), which can increase following compost application (Alvarenga et al. 2008a). The presence of plants reversed the response of urease, with greatest values in amended soil, presumably because uptake by plants decreased the level of ammonium, potassium, and sodium in soil.

Table 4 Loadings for each variable along PC1 and PC2 resulting from principal component analysis of parameters in fertilized or amended soil with plants

\begin{tabular}{llc}
\hline Variable & PC 1 & PC 2 \\
\hline B. maxima & $0.9484^{*}$ & 0.0174 \\
C. fasciculatus & 0.03980 & $0.8616^{*}$ \\
S. purpurea & 0.0153 & $-0.8488^{*}$ \\
Urease activity & $0.9348^{*}$ & 0.2033 \\
Phosphatase activity & $0.8523^{*}$ & -0.2596 \\
Glucosidase activity & $0.9620^{*}$ & 0.0139 \\
Dehydrogenase activity & 0.1845 & $0.9451^{*}$ \\
Cellulase activity & $0.9738^{*}$ & 0.0772 \\
Protease activity & $0.9286^{*}$ & 0.3292 \\
Microbial respiration & $0.9148^{*}$ & 0.1430 \\
\hline
\end{tabular}

PC1 first principal component; $P C 2$ second principal component

${ }^{\text {a }}$ Marked correlations are significant (correlation coefficient $>0.7$ ) 


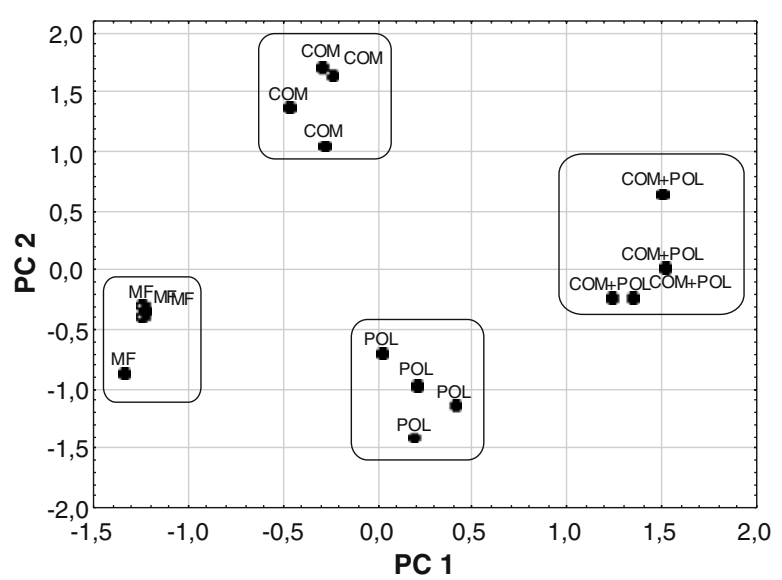

Fig. 3 Principal component analysis (left) and cluster analysis (right) of treatments at the end of the experiment in fertilized or amended soil with plants. $M F$ mineral fertilizer; $C O M$ compost;

The presence of plants also changed the relationship between soil parameters, probably because the three species responded differently to amendments. This was not trivial as biomass accumulation in the best treatment for each species was at least $60 \%$ greater than the second best.

In the presence of plants, no amendment could be considered to be superior to the other. Application of both compost and polymer stimulated the growth of $B$. maxima and was related to the greatest values for most soil parameters, while the treatment with compost on its own favored the growth of $C$. fasciculatus and led to the greatest value of dehydro-

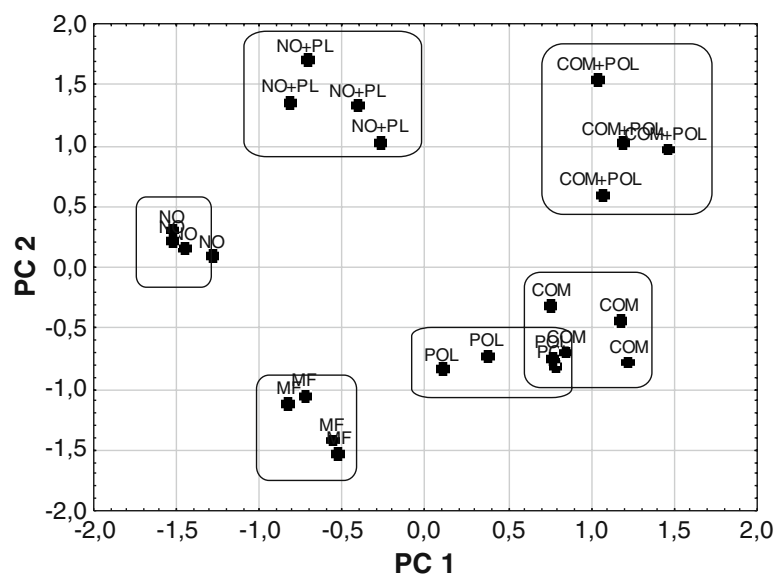

Fig. 4 Principal component analysis (left) and cluster analysis (right) of treatments at the end of the experiment in bare soil or in unfertilized soil with plants. $N O$ control with no fertilizer or

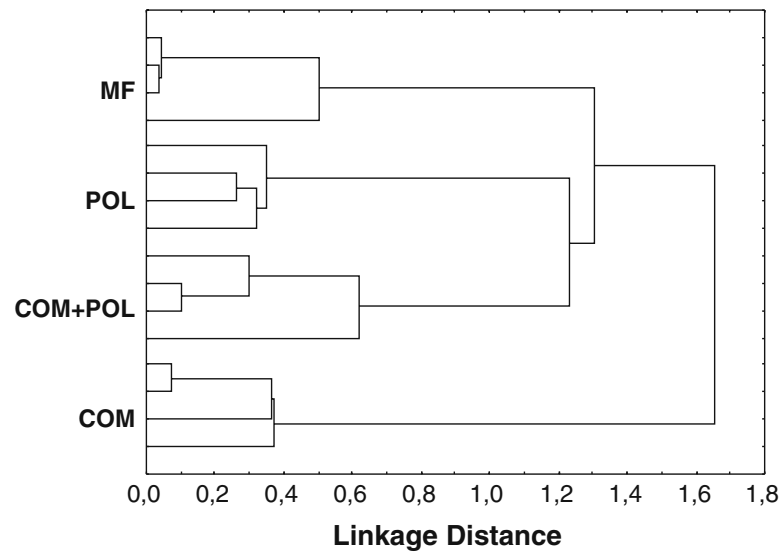

$P O L$ polymers; $P C 1$ and $P C 2$ principal components 1 and 2, respectively

genase activity. Polymer application was related to the greatest biomass accumulation by $S$. purpurea but led to smaller or similar values of soil parameters, compared to the other two treatments.

The differential effects of treatments on dehydrogenase and basal respiration suggest a change in microbial communities, which is reinforced by the effects on soil enzymes. This aspect deserves further investigation.

In conclusion, the amendments tested improved the quality of a mine soil and stimulated plant growth. However, changes varied according to the dominant plant species and type of amendment. This interaction

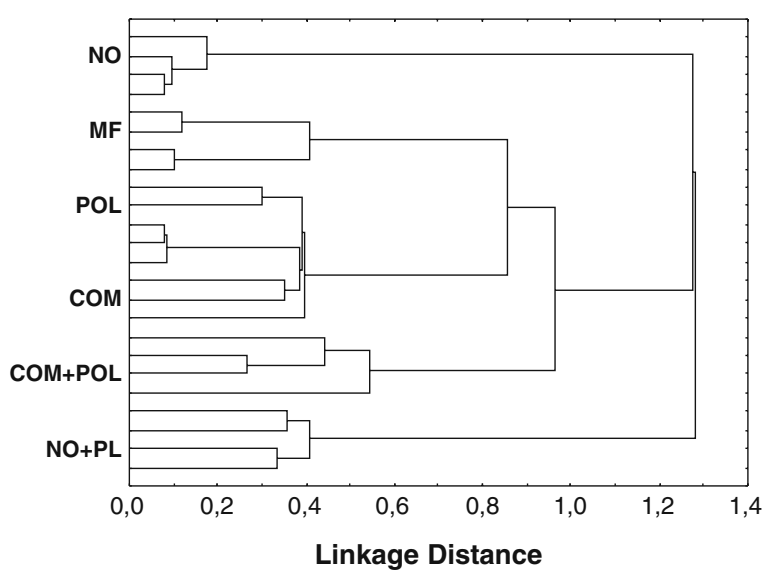

amendments; $M F$ mineral fertilizer; $C O M$ compost; $P O L$ polymers; $P L$ plants; $P C 1$ and $P C 2$ principal components 1 and 2 , respectively 
should be taken into consideration when a large scale application of amendments is projected, as it could lead to loss of biodiversity. Conversely, if amendments are managed carefully, they could be used to increase the contribution of more valuable species.

Acknowledgements This study was funded by the project PPTDC/AMB/57586/2004 from the Fundação para a Ciência e a Tecnologia (FCT). Qu Guiwei is grateful for the grant SFRH/ BD/21430/2005 from the FCT. We thank Paula Gonçalves Silva for technical assistance.

\section{References}

Al-Humaid, A. I., \& Moftah, A. E. (2007). Effects of hydrophilic polymers on the survival of buttonwood seedlings grown under drought stress. Journal of Plant Nutrition, 30, 53-66.

Alvarenga, P. M. L. F., Goncalves, A. P., Fernandes, R. M. C. S., de Varennes, A., Duarte, E. C. N. F. A., Vallini, G., et al. (2008a). Effect of organic residues and liming materials on metal extraction from a mining-contaminated soil. Bioremediation Journal, 12, 58-69.

Alvarenga, P., Palma, P., Gonçalves, A. P., Baião, N., Fernandes, R. M., de Varennes, A., et al. (2008b). Assessment of chemical, biochemical and ecotoxicological aspects in a mine soil amended with sludge of either urban or industrial origin. Chemosphere, 72, 1774-1781.

Boatright, J. L., Balint, D. E., Mackay, W. A., \& Zajicek, J. M. (1997). Incorporation of a hydrophilic polymer into annual landscape beds. Journal of Environmental Horticuture, 15, 37-40.

Brown, S. L., Henry, C. H., Chaney, R., Compton, H., \& Volder, P. S. D. (2003). Using municipal biosolids in combination with other residuals to restore metalcontaminated areas. Plant and Soil, 249, 203-215.

Campbell, C. D., Chapman, S. J., Cameron, C. M., Davidson, M. S., \& Potts, J. M. (2003). A rapid microtiter plate method to measure carbon dioxide evolved from carbon substrate amendments so as to determine the physiological profiles of soil microbial communities by using whole soil. Applied and Environmental Microbiology, 69, 3593-3599.

Clemente, R., Almela, C., \& Bernal, M. P. (2006). A remediation strategy based on active phytoremediation followed by natural attenuation in a soil contaminated by pyrite waste. Environmental Pollution, 143, 397-406.

Cookson, P. (1999). Spatial variation of soil urease activity around irrigated date palms. Arid Soil Research and Rehabilitation, 13, 155-169.

de Varennes, A., \& Queda, C. (2005). Application of an insoluble plyacrylate polymer to copper-contaminated soil enhances plant growth and soil quality. Soil Use and Management, 21, 410-414.

de Varennes, A., Torres, M. O., Conceição, E., \& Vasconcelos, E. (1999). Effect of polyacrylate polymers with different counter ions on the growth and mineral composition of perennial ryegrass. Journal of Plant Nutrition, 22, 33-43. de Varennes, A., Goss, M. J., \& Mourato, M. (2006). Remediation of a sandy soil contaminated with cadmium, nickel and zinc using an insoluble polyacrylate polymer. Communications in Soil Science and Plant Analysis, 37, 1639-1649.

Dick, R. P., Rasmussen, P. E., \& Kerle, E. A. (1988). Influence of long-term residue management on soil enzyme activities in relation to soil chemical properties of a wheatfallow system. Biology and Fertility of Soils, 6, 159-164.

DG Env.A.2. (2001). Working document of biological treatment of biowaste - 2nd draft. Directorate-General Environment, http://europa.eu.int/comm/environment/waste/ facts_en.htm, Accessed 10 September 2002.

DG Env.A.2. (2003). Draft discussion document for the AD HOC meeting on biowastes and sludges. Directorate-General Environment. http://forum.europa.eu.int/Public/irc/env/soil/ library?1=/biowastesandssludge/adshocsmeetings1516sjanu/ draftsdiscussionsdocumen/_EN_1.0_\&a=d Accessed on 15 May 2005.

Dudka, S., \& Miller, W. P. (1999). Permissible concentrations of arsenic and lead in soils based on risk assessment. Water, Air and Soil Pollution, 113, 127-132.

Eddouksa, M., Jouada, H., Maghrania, M., Lemhadria, A., \& Burcelinb, R. (2003). Inhibition of endogenous glucose production accounts for hypoglycemic effect of Spergularia purpurea in streptozotocin mice. Phytomedicine, 10, 594-599.

Eivazi, F., \& Tabatabai, M. A. (1977). Phosphatases in soils. Soil Biology and Biochemistry, 9, 167-172.

Eivazi, F., \& Tabatabai, M. A. (1988). Glucosidases and galactosidases in soils. Soil Biology and Biochemistry, 20, 601-606.

Farfel, M. R., Orlova, A. O., Chaney, R. L., Lees, P. S. J., Rohde, C., \& Ashley, P. (2005). Biosolids compost amendment for reducing soil lead hazards: A pilot study in urban yards. Science of the Total Environment, 340, 8195.

Friesl, W., Lombi, E., Horak, O., \& Wenzel, W. (2003). Immobilization of heavy metals in soils using inorganic amendments in a greenhouse study. Journal of Plant Nutrition and Soil Science, 166, 191-196.

García-Gil, J. C., Plaza, C., Soler-Rovira, P., \& Polo, A. (2000). Long-term effects of municipal solid waste compost application on soil enzyme activities and microbial biomass. Soil Biology and Biochemistry, 32, 1907-1913.

Gaskin, J. W., Brobst, R. B., Miller, W. P., \& Tollner, E. W. (2003). Long-term biosolids application effects on metal concentrations in soil and bermudagrass forage. Jouirnal of Environmental Quality, 32, 146-152.

Geebelen, W., Adriano, D. C., van der Lelie, D., Mench, M., Carleer, R., Clijsters, H., et al. (2003). Selected bioavailability assays to test the efficacy of amendment-induced immobilization of lead in soil. Plant and Soil, 249, 217228.

Guiwei, Q., de Varennes, A., \& Cunha-Queda, C. (2008). Remediation of a mine soil with insoluble polyacrylate polymers enhances soil quality and plant growth. Soil Use and Management, 24, 350-356.

Hope, C. F. A., \& Burns, R. G. (1987). Activity, origins and location of cellulase in a silt loam soil. Biology and Fertility of Soils, 5, 164-170. 
Illera, V., Walter, I., Souza, P., \& Cala, V. (2000). Short-term effects of biosolid and municipal waste applications on heavy metals distribution in a degraded soil under semi-arid environment. Science of the Total Environment, 255, 29-44.

Iyyemperumal, K., \& Shi, W. (2008). Soil enzyme activities in two forage systems following application of different rates of swine lagoon effluent or ammonium nitrate. Applied Soil Ecology, 38, 128-136.

Jouad, H., Lacaille-Dubois, M. A., \& Eddouks, M. (2001). Chronic diuretic effect of the water extract of Spergularia purpurea in normal rats. Journal of ethnopharmacology, 75, 219-223.

Kandeler, E., \& Gerber, H. (1988). Short-term assay of soil urease activity using colorimetric determination of ammonium. Biology and Fertility of Soils, 6, 68-72.

Korboulewsky, N., Dupouyet, S., \& Bonin, G. (2002). Environmental risks of applying sludge compost to vineyards: Carbon, heavy metals, nitrogen, and phosphorous accumulation. Journal of Environmental Quality, 31, $1522-1527$.

Lindim, C., de Varennes, A., Torres, M. O., \& Mota, A. M. (2001). Remediation of a sandy soil artificially contaminated with cadmium using a polyacrylate polymer. Communications in Soil Science and Plant Analysis, 32, 1567-1574.

Martin, E. (1996). Environmental impact studies of the disposal of polyacrylate polymers used in consumer products. Science of the Total Environment, 19, 225-234.

Nannipieri, P., Kandeler, E., \& Ruggiero, P. (2002). Enzyme activities and microbiological and biochemical processes, in soil. In R. G. Burns \& R. P. Dick (Eds.), Enzymes in the environment: Activity, ecology and applications (pp. 133). New York: Dekker.

Pérez-de-Mora, A. P., Ortega-Calvo, J. J., Cabrera, F., \& Madejón, E. (2005). Changes in enzyme activities and microbial biomass after "in situ" remediation of heavy metalcontaminated soil. Applied Soil Ecology, 28, 125-137.

Pérez-de-Mora, A. P., Burgos, P., Madejón, E., Cabrera, F., Jaeckel, P., \& Schloter, M. (2006a). Microbial community structure and function in a soil contaminated by heavy metals: Effects of plant growth and different amendments. Soil Biology and Biochemistry, 38, 327-341.

Pérez-de-Mora, A., Madejón, E., Burgos, P., \& Cabrera, F. (2006b). Trace elements availability and plant growth in a mine-spill-contaminated soil under assisted natural remediation II. Plants. Science of the Total Environment, 363, 38-45.

Pérez-de-Mora, A., Madrid, F., Cabrera, F., \& Madejón, E. (2007). Amendments and plant cover influence on trace element pools in a contaminated soil. Geoderma, 139, 110 .

Pichtel, J. R., Dick, W. A., \& Sutton, P. (1994). Comparison of amendments and management-practices for long-term reclamation of abandoned mine lands. Journal of Environmental Quality, 23, 766-772.

Silberbush, M., Adar, E., \& de Malach, Y. (1993). Use of a hydrophilic polymer to improve water storage and availability to crops grown in sand dunes. I. Corn irrigated by trickling. Agricultural Water Management, 23, 303-313.

Tabatabai, M. A. (1994). Soil enzymes. In S. H. Mickelson \& J. M. Bigham (Eds.), Methods of soil analysis, part 2 (pp. 775-833). Madison: SSSA.

Walker, D. J., Clemente, R., Roig, A., \& Bernal, M. P. (2003). The effects of soil amendments on heavy metal bioavailability in two contaminated Mediterranean soils. Environmental Pollution, 122, 303-312.

Walker, D. J., Clemente, R., \& Bernal, M. P. (2004). Contrasting effects of manure and compost on soil $\mathrm{pH}$, heavy metal availability and growth of Chenopodium album L. in a soil contaminated by pyritic mine waste. Chemosphere, 57, 215-224.

Wong, M. H. (2003). Ecological restoration of mine degraded soils, with emphasis on metal contaminated soils. Chemosphere, 50, 775-780.

Yang, L., Li, T., Li, F., Lemcoff, J. H., \& Cohen, S. (2008). Fertilization regulates soil enzymatic activity and fertility dynamics in a cucumber field. Scientia Horticulturae, 116, 21-26. 